\title{
Bistrand Abasic Site
}

National Cancer Institute

\section{Source}

National Cancer Institute. Bistrand Abasic Site. NCI Thesaurus. Code C19572.

Location on a DNA strand where the phosphate backbone is intact but the nitrogenous base has been lost from both DNA strands. 